\title{
HPyV6 and HPyV7 in urine from immunocompromised patients
}

\author{
Carla Prezioso ${ }^{1,2}$, Marijke Van Ghelue ${ }^{3,4}, U$ go Moens ${ }^{*^{*}}$ and anderia Pietropaolo ${ }^{1^{*}}$
}

\begin{abstract}
Background: Human polyomavirus 6 (HPyV6) and HPyV7 are two of the novel polyomaviruses that were originally detected in non-diseased skin. Serological studies have shown that these viruses are ubiquitous in the healthy adult population with seroprevalence up to $88 \%$ for HPyV6 and 72\% for HPyV7. Both viruses are associated with pruritic skin eruption in immunocompromised patients, but a role with other diseases in immunoincompetent patients or malignancies has not been established.
\end{abstract}

Methods: PCR was used to determine the presence of HPyV6 and HPyV7 DNA in urine samples from systemic lupus erythematosus $(n=73)$, multiple sclerosis $(n=50)$, psoriasis vulgaris $(n=15)$, arthritic psoriasis $(n=15)$ and HIVpositive patients $(n=66)$. In addition, urine from pregnant women $(n=47)$ and healthy blood donors $(n=20)$ was investigated.

Results: HPyV6 DNA was detected in 21 (28.8\%) of the urine specimens from SLE patients, in 6 (9.1\%) of the urine samples from the HIV-positive cohort, and in 19 (40.4\%) samples from pregnant women. HPyV7 DNA was only found in 6 (8.2\%) of the urine specimens from SLE patients and in 4 (8.5\%) samples from pregnant women. No HPyV6 and HPyV7 viruria was detected in the urine samples from the other patients.

Conclusions: HPyV6, and to a lesser extend HPyV7, viruria seems to be common in SLE and HIV-positive patients, and pregnant women. Whether these viruses are of clinical relevance in these patients is not known.

Keywords: Blood donor, HIV, Human polyomaviruses, Immunocompromised, Multiple sclerosis, PCR, Pregnant women, Psoriasis, Viruria

\section{Background}

A virus was isolated in the 1950ies from mouse and because of its ability to induce multiple tumors in animal models named polyomavirus (PyV) [1]. Since then, PyVs have been described in other mammals, including humans, birds, and fish [2,3]. Members of the Polyomaviridae family are characterized by non-enveloped virus particles containing a circular double-stranded DNA genome of approximately 5000 base-pairs (bp). A

\footnotetext{
*Correspondence: ugo.moens@uit.no; valeria.pietropaolo@uniroma1.it 1 Department of Public Health and Infectious Diseases, "Sapienza" University of Rome, Rome, Italy

${ }^{5}$ Department of Medical Biology, Faculty of Health Sciences, University of Troms $\varnothing$ - The Arctic University of Norway, Tromsø, Norway

Full list of author information is available at the end of the article
}

typical PyV genome codes for the regulatory proteins large T-antigen (LT) and small T-antigen (sT) and at least two capsid proteins, VP1 and VP2. The T-antigens are expressed early during the infection cycle, and are required for viral transcription and replication [4]. These proteins possess oncogenic properties [5-7]. The capsid proteins are expressed after viral replication has initiated and therefore later during infection of the host cell. A non-coding region (NCCR), which encompasses the origin of replication and the transcription regulatory sequences for both the T-antigens and the VPs, separates the coding regions for the $\mathrm{T}$-antigens and capsid proteins [4].

So far, 15 polyomavirus genomes have been isolated from humans. In 1971, BKPyV and JCPyV were the first original author(s) and the source, provide a link to the Creative Commons licence, and indicate if changes were made. The images or other third party material in this article are included in the article's Creative Commons licence, unless indicated otherwise in a credit line to the material. If material is not included in the article's Creative Commons licence and your intended use is not permitted by statutory regulation or exceeds the permitted use, you will need to obtain permission directly from the copyright holder. To view a copy of this licence, visit http://creativecommons.org/licenses/by/4.0/. The Creative Commons Public Domain Dedication waiver (http://creativeco mmons.org/publicdomain/zero/1.0/) applies to the data made available in this article, unless otherwise stated in a credit line to the data. 
human PyVs to be described in literature. They were isolated from urine of a renal transplant patient and the brain from a patient with progressive multifocal encephalopathy (PML), respectively $[8,9]$. Since then, novel PyVs were originally described in nasopharyngeal aspirates (KIPyV; [10]), bronchoalveolar lavage (WUPyV; [11]), Merkel cell carcinoma (MCPyV; [12]), skin (HPyV6, HPyV7, TSPyV, LIPyV; [13-15]), serum (HPyV9; [16]), genital warts (HPyV10; [17]), feces (STLPyV, QPyV; [18, 19]), liver (HPyV12; [20]), and muscle (NJPyV; [21]). Although HPyVs seem to establish a harmless persistent infection in healthy individuals [22, 23], they may cause diseases in immunocompromised patients. BKPyV is associated with nephropathy in renal transplant recipients and hemorrhagic cystitis in hematopoietic stem cell transplantation [24, 25]. JCPyV causes PML and few cases of JCPyV-associated nephropathy in renal transplant patients have been observed [26-28]. MCPyV is the cause of Merkel cell carcinoma, a neuroendocrine skin cancer [12], and TSPyV is the etiological factor of trichodysplasia spinulosa in immunodeficient patients [29].

Serological studies have demonstrated that HPyV6 and HPyV7 infections are ubiquitous in the healthy adult human population, with a seroprevalence ranging between 74 and $93 \%$ for HPyV6 and between 56 and $80 \%$ for HPyV7 [30-34]. The presence of HPyV6 and HPyV7 DNA has been examined in different biological samples of healthy controls and different patient groups in a quest to determine the cell tropism and the possible association of these viruses with diseases. HPyV6 and HPyV7 are natural inhabitants of the healthy skin virome [13, 35-39]. These viruses have been detected in other specimens. HPyV6 was present in the urine from one out of 70 patients with hemorrhagic cystitis [40], and HPyV7 was found in urine from one out of 100 liver transplant patients [41] and from five out of 43 hematopoietic stem cell transplant patients [40]. HPyV6, but not HPyV7, was detected in cerebrospinal fluid (CSF) from one out of 243 neurological patients [42] and from one HIV-positive patient with JCPyV-negative progressive multifocal leukoencephalopathy [43]. HPyV6 DNA could be amplified from two out 110 serum samples from HIV-negative patients [44], and from nasopharyngeal aspirates [45] and lymph nodes [46]. HPyV7 DNA was present in the blood from a patient with dyskeratotic dermatosis [47]. Both viruses are also present in eyebrow hair from healthy men [38], and in cervical specimens of women [48].

Clear associations with diseases have not been established, except in severely immunocompromised patients, where HPyV6 and HPyV7 can cause pruritic dermatoses characterized by hyperproliferation of dyskeratotic (with premature or altered differentiation) keratinocytes that result in brownish skin plaques [49-53]. The presence of HPyV6 has sporadically been detected in the skin from lichen simplex chronicus, eosinophilic pustular folliculitis and suppurative foliculitis patients [39, 54]. HPyV6 has also been associated with Kimura disease and patients with dermatopathic lymphadenitis [46, 55]. HPyV6, but not HPyV7 DNA was present in anal/ rectal swabs of some men who had sex with men that were HIV-negative, but neither HPyV6 nor HPyV7 were detected in throat/oral swabs and in urethral specimens from these subjects [56].

A role for HPyV6 and HPyV7 in human cancers is lacking although low viral genome copy numbers have been found in few samples of different tumor tissue types [39, $44,57-69]$.

To further exploit a possible causative role of HPyV6 and HPyV7 in immunocompromised patients, we examined the presence of DNA from these viruses in urine from systemic lupus erythematosus (SLE), HIV positive, psoriasis, and multiple sclerosis patients, as well as in urine from pregnant women and healthy blood donors. HPyV6 viruria was found in SLE patients, HIV-positive patients and pregnant women, whereas HPyV7 DNA was only detected in SLE and HIV-positive patients. The prevalence of HPyV6 was higher than HPyV7 in these two patient groups. Longitudinal study of the SLE patients showed intermittent viruria.

\section{Methods}

\section{Patients' samples}

Archival urine samples from five anonymous SLE patients (four women and one man) from Stavanger (Norway) were used. These samples were acquired over a 1-year period. In total, 73 samples were collected [70]. Forty-seven single archival urine specimens from healthy women who were 18-39 weeks pregnant, collected at the university hospital of Northern Norway, have been previously described [70]. The urine samples were stored as $1 \mathrm{ml}$ aliquots in a $-20{ }^{\circ} \mathrm{C}$ freezer that was only used for storage of samples. The freezer stands in a different room separated from the lab, PCR room and post PCR room. The urine samples from SLE patients and from pregnant women were kept in separate drawers in the $-20{ }^{\circ} \mathrm{C}$ freezer. The study was approved by the Regional Committees for Medical and Health Research Ethics (REK; reference number 2012/420). Fifty urine samples were obtained from a cohort of 30 relapsing remitting multiple sclerosis (RRMS) subjects, followed up at the Department of Human Neurosciences of Sapienza University of Rome and recruited between March 2016 and March 2018. All participants fulfilled the Italian Agency of Drug (AIFA) criteria for natalizumab treatment and the therapeutic protocol consisted of administration of $300 \mathrm{mg}$ 
intravenous natalizumab every 4 weeks. The enrolled patients (12 males/18 females, mean age \pm stand. dev: $30.2 \pm 6.6$; mean months of illness \pm stand. dev. $85 \pm 85.5$; mean Expanded Disability Status Scale (EDSS) \pm stand. dev. $1.9 \pm 1.3)$ were visited before natalizumab treatment (baseline: 0 infusions) and after infusions at weeks 4, 8, 12, 16 and 20. Patients signed informed consent based on the approved Ethic Committee of Policlinico Umberto I of Rome (protocol number 130/13). Sixtysix urine specimens were collected from a cohort of 66 HIV-1-positive patients, admitted to the Infectious Diseases Clinic of the Polyclinic Tor Vergata Foundation from January 2019 to December 2019. Among the enrolled patients ( 55 males/11 females, age ranged from 21 to 76 years old: mean age \pm stand. dev: 40.5 years old; median: 39.9 years old) 22 were new diagnoses naive to treatment and 44 were experienced patients on treatment with a triple-based antiretroviral regimen including protease/reverse transcriptase/integrase inhibitors. The study was approved by the local Ethic Committee of the University Hospital Tor Vergata (Rome, Italy) (protocol number 0027234/2018, 19 December 2018), and patients informed consent was ascertained. Healthy donors $(n=20)$, aged $18 \pm 63$ years, were recruited from blood donors attending the Italian Red Cross Blood Transfusion Centre in Rome (RMTC) and a sample of urine was obtained. Thirty urine specimens were collected from a cohort of 30 psoriasis patients, of both genders with a mean age of $33 \pm 4$ years, referred to the Dermatology Institute IDI IRCSS of Rome. One group of subjects, consisting of 15 patients, diagnosed with psoriasis vulgaris and the another 15 patients were diagnosed with psoriatic arthritis. These subjects did not show other autoimmune and chronic diseases. Informed consent was obtained from all patients.

\section{DNA purification and $\mathrm{PCR}$}

DNA was purified from $200 \mu$ urine samples. The samples were centrifuged for $1 \mathrm{~min}$ at 12,000 g to remove cell debris. DNA purification was performed on cell-cleared urine using the QIAamp MinElute Virus Spin Kit according to the manufacturer's instructions (Qiagen, Hilden, Germany; cat. No. 57704). DNA was eluted in $50 \mu \mathrm{l}$ and $5 \mu \mathrm{l}$ was used in PCR. The following primers were used to amplify a $299 \mathrm{bp}$ fragment of LT: HPyV6LT.F: CAA TGCATCACTACCTGGAC (nucleotides 4316-4335 in isolate 601a; HM011558) and HPyV6LT.R: GTTTGG GATTTCCGTTTGTG (nucleotides 4595-4614 in isolate 601a; HM011558). For HPyV7, a 344 bp fragment of LT was amplified using the primers HPyV7LT.F: CACGCA GGGCTTCCATATGG (nucleotides 4267-4282 in isolate 713a; HM011586) and HPyV7LT.R: GGTTTAAGA GCCTGCTGTTG-3' (nucleotides 4591-4610 in isolate 713a; HM011586). The PCR conditions were 40 cycles of $30 \mathrm{~s}$ at $90{ }^{\circ} \mathrm{C}, 30 \mathrm{~s}$ at $55^{\circ} \mathrm{C}$, and $1 \mathrm{~min}$ at $72{ }^{\circ} \mathrm{C}$. PCR was performed with Accustart II PCR SuperMix (Qunatabio, Beverly, MA, USA; cat. no. 95137-500). The plasmids pHPyV6-607a (Addgene, Watertown, MA, USA; cat. no. 24727) and pHPyV7-713a (Addgene; cat. no. 24728) were used as positive controls and to test the sensitivity of our PCR.

\section{Statistical analysis}

HPyV6 and HPyV7 detection were summarized by counts and proportions. If continuous variables were normally distributed, they were expressed as mean $\pm S D$; if not, they were expressed by median and range. The $X^{2}$ test was performed to evaluate differences in the viral detection and the Mann-Whitney U-test for non-normally distributed continuous variables was applied to analyse differences between patients. A $p$ value $<0.05$ was considered statistically significant.

\section{Results}

To investigate whether other immunocompromised conditions may lead to viruria of HPyV6 and HPyV7, urine specimens of five cohorts were examined for the presence of DNA of these viruses. The cohorts included: systemic lupus erythematosus (SLE) patients, multiple sclerosis patients, HIV-positive patients, psoriasis patients and pregnant women. HPyV6 DNA was detected in $28.8 \%$ of the urine specimens from SLE patients and in $40.4 \%$ of the samples from pregnant women (Table 1). No HPyV6

Table 1 DNA prevalence of HPyV6 and HPyV7 in different patient groups

\begin{tabular}{lll}
\hline Patient group ( $\mathbf{n})$ & HPyV6 (\%) & HPyV7 (\%) \\
\hline SLE (5) & & \\
SLE1 (5 samples) & $1(20.0)$ & $0(0)$ \\
SLE2 (7 samples) & $1(14.3)$ & $0(0)$ \\
SLE3 (13 samples) & $4(30.8)$ & $2(15.4)^{\mathrm{a}}$ \\
SLE4 (16 samples) & $4(25.0)$ & $3(18.8)^{\mathrm{b}}$ \\
SLE5 (32 samples) & $11(34.4)$ & $1(3.1)^{\mathrm{c}}$ \\
Total samples (73) & $21(28.8)$ & $6(8.2)$ \\
Multiple sclerosis (30) & $0(0)$ & $0(0)$ \\
Psoriasis vulgaris (15) & $0(0)$ & $0(0)$ \\
Arthritic psoriasis (15) & $0(0)$ & $0(0)$ \\
HIV-positive (66) & $6(9.1)$ & $0(0)$ \\
Pregnant women (47) & $19(40.4)$ & $4(8.5)^{\mathrm{d}}$ \\
Blood donors (20) & $0(0)$ & $0(0)$ \\
\hline
\end{tabular}

\footnotetext{
a These samples were also HPyV6 positive

${ }^{b}$ One sample was also HPyV6 positive

c This sample was also HPyV6 positive

d Two samples were also positive for HPyV6
} 
could be amplified in urine from multiple sclerosis and psoriasis patients and from healthy blood donors. HPyV7 DNA was only detected in urine from SLE and pregnant women, although with a lower prevalence than HPyV6 (8.2\% and $8.5 \%$, respectively). The HPyV7-positive urine samples from SLE patient 3 were also HPyV6 positive. Two unique urine samples from SLE patient 4 and patient 5 contained both HPyV6 and HPyV7. Of the four HPyV7 positive urine samples from pregnant women, two were also positive for HPyV6. Six of the HIV-positive patients had HPyV6 viruria, but none had HPyV7 viruria. Interestingly, the six HIV patients with a HPyV6 positive urine sample were naïve, i.e., they had just started HAART treatment. HPyV6 and HPyV7 was not detected in any of the urine specimens from healthy blood donors, multiple sclerosis patients and psoriasis patients. No significant association was found between the presence of HPyV6 and HPyV 7 DNA versus age and gender when applicable, and HPyV6 and HPyV7 DNA versus disease $(p<0.05)$.

\section{Discussion}

HPyV6 and HPyV7 DNA has been detected in different body samples of immunocompromised patients [39, 43, 49-53], but viruria of these viruses has not been examined in SLE and MS patients and in pregnant women. We found that DNA of both viruses was detected in the urine from some SLE patient and pregnant women, with a higher prevalence of HPyV6 compared to HPyV7. A previous study failed to detect HPyV6 and HPyV7 DNA in skin from two SLE patients [39]. Similar to HPyV6 and $\mathrm{HPyV7}$, intermittent episodes of urine shedding of $\mathrm{BKPyV}$ and JCPyV and simultaneous viruria of BKPyV and JCPyV was observed in SLE patients [70-75].

We could not detect HPyV6 or HPyV7 urine shedding in MS patients treated with natalizumab. CSF from 10 MS patients were negative for HPyV6 and HPyV7 DNA [42], suggesting that reactivation of these two HPyVs may be a rare event in MS patients. Studies by several groups have shown that BKPyV, JCPyV or both can be detected in urine from MS patients receiving natalizumab or $\beta$-interferon [76-81], indicating that HPyV viruria is not uncommon in these patients.

We did not discover HPyV6 and HPyV7 DNA in the urine samples of healthy blood donors. This is in agreement with a previous study that also failed to detect HPyV6 in the urine from 50 healthy volunteers [82] or in 189 urine specimens from symptomatic children and adults undergoing routine diagnostic testing [83]. A longitudinal study on 169 urine samples obtained from 32 organ transplant patients showed only one urine sample positive for HPyV7 DNA. This sample was obtained from a liver transplant child 8 months after transplantation [41].
The presence of HPyV6, but not HPyV7 DNA has been described in CSF, serum, and anal/rectal swabs from HIV-positive individuals [42, 43, 56], but neither HPyV6 nor $\mathrm{HPyV} 7$ were found in urethral samples or urine [56, 84]. We found that 6 of our $66 \mathrm{HIV}$-positive subjects displayed HPyV6 viruria, whereas Torres et al, examined only 19 urine samples [84]. The relative small number of subjects in the latter study may explain the different findings with our results.

Hashida and colleagues examined nonlesional and lesional skin swabs from 30 psoriasis patients and reported that $58 \%$ (nonlesional) and 54\% (lesional) samples were HPyV6 positive, while the HPyV7 prevalence was $42 \%$ and $25 \%$. Of the skin swabs from healthy individuals, $14 \%$ were positive for HPyV 6 and $6 \%$ were positive for HPyV7. The viral loads were also higher in both nonlesional and lesional samples of the psoriasis patients compared to the healthy individuals, indicating that HPyV6 and HPyV7 infection is higher in this inflammatory skin condition [85].

While PCR-based studies have shown that BKPyV and JCPyV viruria is common in pregnant women [86-89], less is known about urinal excretion of the novel HPyV. Cosma et al. [90] examine KIPyV, WUPyV and HPyV9 viruria in 100 non-pregnant and 100 pregnant women and found HPyV9 viruria in 2 non-pregnant and 3 pregnant women, whereas no KIPyV and WUPyV was detected in either cohorts. To the best of our knowledge, HPyV6 and HPyV7 viruria has not been investigated in pregnant women. We found that $40.4 \%$ of the women were positive for HPyV6 and $8.5 \%$ were positive for HPyV7. Two of the women (4.3\%) had a urine sample that contained DNA of both viruses.

\section{Conclusions}

In conclusion, immunodeficient conditions in SLE and HIV-positive patients may lead to viruria of HPyV6 and HPyV7, but whether these observations are linked to clinical conditions remain to be further explored. Our longitudinal study on SLE patients show that some of these patients may have intermitted episodes of HPyV6/7 reactivation.

\section{Abbreviations}

CSF: Cerebrospinal fluid; HPyV: Human polyomavirus; MS: Multiple sclerosis; VP: Viral protein; SLE: Systemic lupus erythematosus.

\section{Acknowledgements}

The APC was funded by UiT, The Arctic University of Norway.

\section{Authors' contributions}

Conceptualization: UM and VP; methodology: CP, MVG, UM, VP, experiments: CP, MVG, UM; validation and formal analysis: CP, MVG, UM, VP; original draft preparation: UM and VP; writing, reviewing and editing the manuscript: $C P$, MVG, UM and VP. All authors read and approved the final manuscript. 


\section{Funding}

This work was supported by the Aakre Foundation (A65285;UM) and Carla Prezioso was supported by the Italian Ministry of Health (starting Grant: SG-2018-12366194).

\section{Availability of data and materials}

All data generated or analyzed during this study are included in this published article.

\section{Ethical approval and consent to participate}

This study was approved by the Regional Committees for Medical and Health Research Ethics, University of Troms $\varnothing$-The Arctic University of Norway (REK; reference number 2012/420).

\section{Consent for publication}

Not applicable.

\section{Competing interests}

The authors declare that they have no competing interests.

\section{Author details}

1 Department of Public Health and Infectious Diseases, "Sapienza" University of Rome, Rome, Italy. ${ }^{2}$ Microbiology of Chronic Neuro-Degenerative Pathologies, IRCSS San Raffaele Pisana, Rome, Italy. ${ }^{3}$ Department of Medical Genetics, Division of Child and Adolescent Health, University Hospital of North Norway, Tromsø, Norway. ${ }^{4}$ Department of Clinical Medicine Faculty of Health Sciences, University of Troms $\varnothing$ - The Arctic University of Norway, Tromsø, Norway. ${ }^{5}$ Department of Medical Biology, Faculty of Health Sciences, University of Troms $\varnothing$ - The Arctic University of Norway, Troms $\varnothing$, Norway.

Received: 3 December 2020 Accepted: 12 January 2021

Published online: 22 January 2021

\section{References}

1. Gross L. A filterable agent, recovered from Ak leukemic extracts, causing salivary gland carcinomas in $\mathrm{C} 3 \mathrm{H}$ mice. Proc Soc Exp Biol Med. 1953;83:414-21.

2. Buck CB, Van Doorslaer K, Peretti A, Geoghegan EM, Tisza MJ, An P, Katz JP, Pipas JM, McBride AA, Camus AC, et al. The ancient evolutionary history of polyomaviruses. PLoS Pathog. 2016;12:e1005574.

3. Calvignac-Spencer S, Feltkamp MC, Daugherty MD, Moens U, Ramqvist T, Johne R, Ehlers B. A taxonomy update for the family Polyomaviridae. Arch Virol. 2016;161:1739-50.

4. Moens U, Krumbholz A, Ehlers B, Zell R, Johne R, Calvignac-Spencer S, Lauber C. Biology, evolution, and medical importance of polyomaviruses: an update. Infect Genet Evol. 2017;54:18-38.

5. Moens U, Van Ghelue M, Johannessen M. Oncogenic potentials of the human polyomavirus regulatory proteins. Cell Mol Life Sci. 2007;64:1656-78.

6. Topalis D, Andrei G, Snoeck R. The large tumor antigen: a "Swiss Army knife" protein possessing the functions required for the polyomavirus life cycle. Antivir Res. 2013;97:122-36.

7. Baez CF, Brandão Varella R, Villani S, Delbue S. Human polyomaviruses: the battle of large and small tumor antigens. Virology (Auckl). 2017:8:1178122-17744785.

8. Padgett BL, Walker DL, ZuRhein GM, Eckroade RJ, Dessel BH. Cultivation of papova-like virus from human brain with progressive multifocal leucoencephalopathy. Lancet. 1971;1:1257-60.

9. Gardner SD, Field AM, Coleman DV, Hulme B. New human papovavirus (B.K.) isolated from urine after renal transplantation. Lancet. 1971;1:1253-7.

10. Allander T, Andreasson K, Gupta S, Bjerkner A, Bogdanovic G, Persson MA, Dalianis T, Ramqvist T, Andersson B. Identification of a third human polyomavirus. J Virol. 2007;81:4130-6.

11. Gaynor AM, Nissen MD, Whiley DM, Mackay IM, Lambert SB, Wu G, Brennan DC, Storch GA, Sloots TP, Wang D. Identification of a novel polyomavirus from patients with acute respiratory tract infections. PLoS Pathog. 2007;3:e64.
12. Feng H, Shuda M, Chang Y, Moore PS. Clonal integration of a polyomavirus in human Merkel cell carcinoma. Science. 2008;319:1096-100.

13. Schowalter RM, Pastrana DV, Pumphrey KA, Moyer AL, Buck CB. Merkel cell polyomavirus and two previously unknown polyomaviruses are chronically shed from human skin. Cell Host Microbe. 2010;7:509-15.

14. van der Meijden E, Janssens RW, Lauber C, Bouwes Bavinck JN, Gorbalenya AE, Feltkamp MC. Discovery of a new human polyomavirus associated with trichodysplasia spinulosa in an immunocompromized patient. PLoS Pathog. 2010;6:e1001024.

15. Gheit T, Dutta S, Oliver J, Robitaille A, Hampras S, Combes JD, McKayChopin S, Le Calvez-Kelm F, Fenske N, Cherpelis B, et al. Isolation and characterization of a novel putative human polyomavirus. Virology. 2017:506:45-54.

16. Scuda N, Hofmann J, Calvignac-Spencer S, Ruprecht K, Liman P, Kühn J, Hengel H, Ehlers B. A novel human polyomavirus closely related to the african green monkey-derived lymphotropic polyomavirus. J Virol. 2011;85:4586-90.

17. Buck CB, Phan GQ, Raiji MT, Murphy PM, McDermott DH, McBride AA. Complete genome sequence of a tenth human polyomavirus. J Virol. 2012;86:10887.

18. Lim ES, Reyes A, Antonio M, Saha D, Ikumapayi UN, Adeyemi M, Stine OC, Skelton R, Brennan DC, Mkakosya RS, et al. Discovery of STL polyomavirus, a polyomavirus of ancestral recombinant origin that encodes a unique $T$ antigen by alternative splicing. Virology. 2013;436:295-303.

19. Ondov BD, Starrett GJ, Sappington A, Kostic A, Koren S, Buck CB, Phillippy AM. Mash Screen: high-throughput sequence containment estimation for genome discovery. Genome Biol. 2019;20:232.

20. Korup S, Rietscher J, Calvignac-Spencer S, Trusch F, Hofmann J, Moens U, Sauer I, Voigt S, Schmuck R, Ehlers B. Identification of a novel human polyomavirus in organs of the gastrointestinal tract. PLoS ONE. 2013;8:e58021.

21. Mishra N, Pereira M, Rhodes RH, An P, Pipas JM, Jain K, Kapoor A, Briese T, Faust PL, Lipkin WI. Identification of a novel polyomavirus in a pancreatic transplant recipient with retinal blindness and vasculitic myopathy. J Infect Dis. 2014;210:1595-9.

22. Doerries K. Human polyomavirus JC and BK persistent infection. Adv Exp Med Biol. 2006;577:102-16.

23. Imperiale MJ, Jiang M. Polyomavirus persistence. Annu Rev Virol. 2016;3:517-32.

24. Leung AY, Yuen KY, Kwong YL. Polyoma BK virus and haemorrhagic cystitis in haematopoietic stem cell transplantation: a changing paradigm. Bone Marrow Transplant. 2005;36:929-37.

25. Ramos E, Drachenberg CB, Wali R, Hirsch HH. The decade of polyomavirus BK-associated nephropathy: state of affairs. Transplantation. 2009;87:621-30.

26. Yang D, Keys B, Conti D, Foulke L, Stellrecht K, Cook L, Lopez-Soler RI. JC polyomavirus nephropathy, a rare cause of transplant dysfunction: case report and review of literature. Transpl Infect Dis. 2017;19(2):12654.

27. Atkinson AL, Atwood WJ. Fifty years of JC polyomavirus: a brief overview and remaining questions. Viruses. 2020;12:969.

28. Cortese I, Reich DS, Nath A. Progressive multifocal leukoencephalopathy and the spectrum of JC virus-related disease. Nat Rev Neurol. 2020;17(1):37-51.

29. Kazem S, van der Meijden E, Feltkamp MC. The trichodysplasia spinulosaassociated polyomavirus: virological background and clinical implications. APMIS. 2013;121:770-2.

30. Nicol JT, Robinot R, Carpentier A, Carandina G, Mazzoni E, Tognon M, Touzé A, Coursaget P. Age-specific seroprevalences of merkel cell polyomavirus, human polyomaviruses 6, 7, and 9, and trichodysplasia spinulosa-associated polyomavirus. Clin Vaccine Immunol. 2013;20:363-8.

31. van der Meijden E, Bialasiewicz S, Rockett RJ, Tozer SJ, Sloots TP, Feltkamp MC. Different serologic behavior of MCPyV, TSPyV, HPyV6, HPyV7 and HPyV9 polyomaviruses found on the skin. PLoS ONE. 2013;8:e81078.

32. Robles C, Casabonne D, Benavente Y, Costas L, Gonzalez-Barca E, Aymerich M, Campo E, Tardon A, Jiménez-Moleón JJ, Castaño-Vinyals G, et al. Seroreactivity against Merkel cell polyomavirus and other polyomaviruses in chronic lymphocytic leukaemia, the MCC-Spain study. J Gen Virol. 2015;96:2286-92.

33. Gossai A, Waterboer T, Nelson HH, Michel A, Willhauck-Fleckenstein M, Farzan SF, Hoen AG, Christensen BC, Kelsey KT, Marsit CJ, et al. Seroepidemiology of human polyomaviruses in a US population. Am J Epidemiol. 2016;183:61-9. 
34. Kamminga S, van der Meijden E, Feltkamp MCW, Zaaijer HL. Seroprevalence of fourteen human polyomaviruses determined in blood donors. PLOS ONE. 2018;13:e0206273.

35. Foulongne V, Sauvage V, Hebert C, Dereure O, Cheval J, Gouilh MA, Pariente $\mathrm{K}$, Segondy M, Burguière A, Manuguerra JC, et al. Human skin microbiota: high diversity of DNA viruses identified on the human skin by high throughput sequencing. PLOS ONE. 2012;7:e38499.

36. Wieland U, Silling $S$, Hellmich M, Potthoff A, Pfister $H$, Kreuter A. Human polyomaviruses 6, 7, 9, 10 and Trichodysplasia spinulosa-associated polyomavirus in HIV-infected men. J Gen Virol. 2014;95:928-32.

37. Wylie KM, Mihindukulasuriya KA, Zhou Y, Sodergren E, Storch GA, Weinstock GM. Metagenomic analysis of double-stranded DNA viruses in healthy adults. BMC Biol. 2014;12:71.

38. Hampras SS, Giuliano AR, Lin HY, Fisher KJ, Abrahamsen ME, McKayChopin S, Gheit T, Tommasino M, Rollison DE. Natural history of polyomaviruses in men: the HPV infection in men (HIM) study. J Infect Dis. 2015;211:1437-46.

39. Fava P, Merlino C, Novelli M, Ponti R, Galliano I, Montanari P, Tovo PA, Fierro MT, Bergallo M. HPyV6, HPyV7 and TSPyV DNA sequences detection in skin disease patients and healthy subjects. J Eur Acad Dermatol Venereol. 2016;30:624-7.

40. Franzén J, Ramqvist T, Bogdanovic G, Grün N, Mattson J, Dalianis T. Studies of human polyomaviruses, with HPyV7, BKPyV, and JCPyV present in urine of allogeneic hematopoietic stem cell transplanted patients with or without hemorrhagic cystitis. Transpl Infect Dis. 2016;18:240-6.

41. Siebrasse EA, Bauer I, Holtz LR, Le BM, Lassa-Claxton S, Canter C, Hmiel P, Shenoy S, Sweet S, Turmelle Y, et al. Human polyomaviruses in children undergoing transplantation, United States, 2008-2010. Emerg Infect Dis. 2012;18:1676-9.

42. Delbue S, Franciotta D, Giannella S, Dolci M, Signorini L, Ticozzi R, D'Alessandro S, Campisciano G, Comar M, Ferrante P, et al. Human polyomaviruses in the cerebrospinal fluid of neurological patients. Microorganisms. 2019;8:16.

43. Delbue S, Elia F, Signorini L, Bella R, Villani S, Marchioni E, Ferrante P, Phan TG, Delwart E. Human polyomavirus 6 DNA in the cerebrospinal fluid of an HIV-positive patient with leukoencephalopathy. J Clin Virol. 2015;68:24-7.

44. Fukumoto $H$, Sato $Y$, Hasegawa $H$, Katano $H$. Frequent detection of Merkel cell polyomavirus DNA in sera of HIV-1-positive patients. Virol J. 2013;10:84.

45. Zheng WZ, Wei TL, Ma FL, Yuan WM, Zhang Q, Zhang YX, Cui H, Zheng LS. Human polyomavirus type six in respiratory samples from hospitalized children with respiratory tract infections in Beijing, China. Virol J. 2015;12:166.

46. Rascovan N, Monteil Bouchard S, Grob JJ, Collet-Villette AM, GaudyMarqueste C, Penicaud M, Lepidi H, Raoult D, Desnues C. Human polyomavirus-6 infecting lymph nodes of a patient with an angiolymphoid hyperplasia with eosinophilia or Kimura disease. Clin Infect Dis. 2016;62:1419-21.

47. Aboudar S, Salmona M, De Masson A, Rivet J, Cardot-Leccia N, MercierDelarue S, Ram-Wolff C, Garnier G, Bouaziz JD, Lebbé C, et al. Diversity and compartmentalization of human polyomavirus 7 in a patient with dyskeratotic dermatosis. J Eur Acad Dermatol Venereol. 2020;34:e609-12.

48. Kolia-Diafouka P, Foulongne V, Boulle N, Ngou J, Kelly H, Sawadogo B, Delany-Moretlwe S, Mayaud P, Segondy M. Detection of four human polyomaviruses (MCPyV, HPyV6, HPyV7 and TSPyV) in cervical specimens from HIV-infected and HIV-uninfected women. Sex Transm Infect. 2016:92:492-4

49. Ho J, Jedrych JJ, Feng H, Natalie AA, Grandinetti L, Mirvish E, Crespo MM, Yadav D, Fasanella KE, Proksell S, et al. Human polyomavirus 7-associated pruritic rash and viremia in transplant recipients. J Infect Dis. 2015;211:1560-5

50. Nguyen KD, Lee EE, Yue Y, Stork J, Pock L, North JP, Vandergriff T, Cockerell C, Hosler GA, Pastrana DV, et al. Human polyomavirus 6 and 7 are associated with pruritic and dyskeratotic dermatoses. J Am Acad Dermatol. 2017;76:932-40.

51. Canavan TN, Baddley JW, Pavlidakey P, Tallaj JA, Elewski BE. Human polyomavirus-7-associated eruption successfully treated with acitretin. Am J Transplant. 2018;18:1278-84.

52. Smith SDB, Erdag G, Cuda JD, Rangwala S, Girardi N, Bibee K, Orens JB, Prono MD, Toptan T, Loss MJ. Treatment of human polyomavirus-7-associated rash and pruritus with topical cidofovir in a lung transplant patient: case report and literature review. Transpl Infect Dis. 2018;20(1):e12793.

53. Rosenstein RK, Pastrana DV, Starrett GJ, Sapio MR, Hill NT, Jo JH, Lee $\mathrm{CR}$, ladarola MJ, Buck CB, Kong HH et al. Host-pathogen interactions in human polyomavirus 7 (HPyV7)-associated pruritic skin eruption. J Investig Dermatol. 2020;S0022-202x(20)32145-X.

54. Hashida Y, Higuchi T, Nakajima S, Nakajima K, Ujihara T, Kabashima K, Sano S, Daibata M. Human polyomavirus 6 detected in cases of eosinophilic pustular folliculitis. J Infect Dis. 2020;jiaaa607.

55. Hashida Y, Higuchi T, Nakajima K, Ujihara T, Murakami I, Fujieda M, Sano S, Daibata M. Human polyomavirus 6 with the Asian-Japanese genotype in cases of kimura disease and angiolymphoid hyperplasia with eosinophilia. J Investig Dermatol. 2020;140:1650-3.

56. Zanotta N, Delbue S, Signorini L, Villani S, D'Alessandro S, Campisciano G, Colli C, De Seta F, Ferrante P, Comar M. Merkel cell polyomavirus is associated with anal infections in men who have sex with men. Microorganisms. 2019;7:54

57. Schrama D, Buck CB, Houben R, Becker JC. No evidence for association of HPyV6 or HPyV7 with different skin cancers. J Investig Dermatol. 2012;132:239-41.

58. Scola N, Wieland U, Silling S, Altmeyer P, Stücker M, Kreuter A. Prevalence of human polyomaviruses in common and rare types of non-Merkel cell carcinoma skin cancer. Br J Dermatol. 2012;167:1315-20.

59. Imajoh M, Hashida Y, Nakajima H, Sano S, Daibata M. Prevalence and viral DNA loads of three novel human polyomaviruses in skin cancers from Japanese patients. J Dermatol. 2013;40:657-60.

60. Schrama D, Groesser L, Ugurel S, Hafner C, Pastrana DV, Buck CB, Cerroni L, Theiler A, Becker JC. Presence of human polyomavirus 6 in mutationspecific BRAF inhibitor-induced epithelial proliferations. JAMA Dermatol. 2014;150:1180-6.

61. Frouin E, Guillot B, Larrieux M, Tempier A, Boulle N, Foulongne V, Girard C, Costes V, Solassol J. Cutaneous epithelial tumors induced by vemurafenib involve the MAPK and Pi3KCA pathways but not HPV nor HPyV viral infection. PLOS ONE. 2014:9:e110478.

62. Beckervordersandforth J, Pujari S, Rennspiess D, Speel EJ, Winnepenninckx V, Diaz C, Weyers W, Haugg AM, Kurz AK, Zur HA. Frequent detection of human polyomavirus 6 in keratoacanthomas. Diagn Pathol. 2016;11:58

63. Bergallo M, Daprà V, Fava P, Ponti R, Calvi C, Montanari P, Novelli M, Quaglino P, Galliano I, Fierro MT. DNA from human polyomaviruses, MWPyV, HPyV6, HPyV7, HPyV9 and HPyV12 in cutaneous T-cell lymphomas. Anticancer Res. 2018;38:4111-4.

64. Purdie KJ, Proby CM, Rizvi H, Griffin H, Doorbar J, Sommerlad M, Feltkamp MC, der Meijden EV, Inman GJ, South AP, et al. The role of human papillomaviruses and polyomaviruses in BRAF-inhibitor induced cutaneous squamous cell carcinoma and benign squamoproliferative lesions. Front Microbiol. 2018;9:1806.

65. Antonsson A, Bialasiewicz S, Rockett RJ, Jacob K, Bennett IC, Sloots TP. Exploring the prevalence of ten polyomaviruses and two herpes viruses in breast cancer. PLoS ONE. 2012;7:e39842.

66. Du-Thanh A, Guillot B, Dereure O, Foulongne V. Detection of Merkel cell and other human polyomavirus DNA in lesional and nonlesional skin from patients with Kaposi sarcoma. Br J Dermatol. 2015;173:1063-5.

67. Rennspiess D, Pujari S, Keijzers M, Abdul-Hamid MA, Hochstenbag M, Dingemans AM, Kurz AK, Speel EJ, Haugg A, Pastrana DV, et al. Detection of human polyomavirus 7 in human thymic epithelial tumors. J Thorac Oncol. 2015:10:360-6.

68. Klufah F, Mobaraki G, Chteinberg E, Alharbi RA, Winnepenninckx V, Speel EJM, Rennspiess D, Olde Damink SW, Neumann UP, Kurz AK, et al. High prevalence of human polyomavirus 7 in cholangiocarcinomas and adjacent peritumoral hepatocytes: preliminary findings. Microorganisms. 2020;8:1125.

69. Chan JF, Tee KM, Choi GK, Zhu Z, Poon RW, Ng KT, Chan KH, Hung IF, Man $K$, Yuen KY. First detection and complete genome sequence of a phylogenetically distinct human polyomavirus 6 highly prevalent in human bile samples. J Infect. 2017;74:50-9.

70. Bendiksen S, Rekvig OP, Van Ghelue M, Moens U. VP1 DNA sequences of JC and BK viruses detected in urine of systemic lupus erythematosus patients reveal no differences from strains expressed in normal individuals. J Gen Virol. 2000;81:2625-33. 
71. Taguchi F, Hara K, Kajioka J, Nagaki D. Isolation of BK virus from a patient with systemic lupus erythematosus (SLE). Microbiol Immunol. 1979;23:1131-2

72. Chang D, Tsai RT, Wang M, Ou WC. Different genotypes of human polyomaviruses found in patients with autoimmune diseases in Taiwan. J Med Virol. 1996;48:204-9.

73. Rekvig OP, Moens U, Sundsfiord A, Bredholt G, Osei A, Haaheim H, Traavik T, Arnesen E, Haga HJ. Experimental expression in mice and spontaneous expression in human SLE of polyomavirus T-antigen. A molecular basis for induction of antibodies to DNA and eukaryotic transcription factors. J Clin Investig. 1997;99:2045-54.

74. Sundsfjord A, Osei A, Rosenqvist H, Van Ghelue M, Silsand Y, Haga HJ, Rekvig OP, Moens U. BK and JC viruses in patients with systemic lupus erythematosus: prevalent and persistent BK viruria, sequence stability of the viral regulatory regions, and nondetectable viremia. J Infect Dis. 1999;180:1-9.

75. Colla L, Mesiano P, Morellini V, Besso L, Cavallo R, Bergallo M, Costa C, Merlino C, Marcuccio C, Fop F, et al. Human polyomavirus BK in patients with lupus nephritis: clinical and histological correlations. Lupus. 2007; 16:881-6

76. Stoner GL, Agostini HT, Ryschkewitsch CF, Komoly S. JC virus excreted by multiple sclerosis patients and paired controls from Hungary. Multiple Scler. 1998;4:45-8.

77. Bellizzi A, Anzivino E, Rodio DM, Cioccolo S, Scrivo R, Morreale M, Pontecorvo S, Ferrari F, Di Nardo G, Nencioni L, et al. Human Polyomavirus JC monitoring and noncoding control region analysis in dynamic cohorts of individuals affected by immune-mediated diseases under treatment with biologics: an observational study. Virol J. 2013;10:298.

78. Lonergan RM, Carr MJ, De Gascun CF, Costelloe LF, Waters A, Coughlan S, Duggan M, Doyle K, Jordan S, Hutchinson MW, et al. Reactivation of BK polyomavirus in patients with multiple sclerosis receiving natalizumab therapy. J Neurovirol. 2009;15:351-9.

79. Delbue S, Elia F, Carloni C, Pecchenini V, Franciotta D, Gastaldi M, Colombo E, Signorini L, Carluccio S, Bellizzi A, et al. JC virus urinary excretion and seroprevalence in natalizumab-treated multiple sclerosis patients. J Neurovirol. 2015;21:645-52.

80. Pietropaolo V, Bellizzi A, Anzivino E, lannetta M, Zingaropoli MA, Rodio DM, Morreale M, Pontecorvo S, Francia A, Vullo V, et al. Human polyomavirus JC replication and non-coding control region analysis in multiple sclerosis patients under natalizumab treatment. J Neurovirol. 2015;21:653-65.

81. Nali LH, Fink MC, do Olival GS, Moraes L, Callegaro D, Tilbery CP, Vidal JE, Sumita LM, de Oliveira AC, Romano CM. Polyomavirus detection in multiple sclerosis patients under natalizumab therapy: profile and frequency of urinary shedding. J Med Virol. 2017;89:528-34.

82. Dolci M, Favero C, Bollati V, Campo L, Cattaneo A, Bonzini M, Villani S, Ticozzi R, Ferrante P, Delbue S. Particulate matter exposure increases JC polyomavirus replication in the human host. Environ Pollut. 2018;241:234-9.

83. Rockett RJ, Sloots TP, Bowes S, O'Neill N, Ye S, Robson J, Whiley DM, Lambert SB, Wang D, Nissen MD, et al. Detection of novel polyomaviruses, TSPyV, HPyV6, HPyV7, HPyV9 and MWPyV in feces, urine, blood, respiratory swabs and cerebrospinal fluid. PLoS ONE. 2013;8:e62764.

84. Torres C, Barrios ME, Cammarata RV, Cisterna DM, Estrada T, Martini Novas S, Cahn P, Blanco Fernández MD, Mbayed VA. High diversity of human polyomaviruses in environmental and clinical samples in Argentina: detection of JC, BK, Merkel-cell, Malawi, and human 6 and 7 polyomaviruses. Sci Total Environ. 2016;542:192-202.

85. Hashida Y, Higuchi T, Tanaka M, Shibata Y, Nakajima K, Sano S, Daibata M. Prevalence and viral loads of cutaneous human polyomaviruses in the skin of patients with chronic inflammatory skin diseases. J Infect Dis. 2019;219:1564-73.

86. Markowitz RB, Eaton BA, Kubik MF, Latorra D, McGregor JA, Dynan WS. BK virus and JC virus shed during pregnancy have predominantly archetypal regulatory regions. J Virol. 1991;65:4515-9.

87. Chang D, Wang M, Ou WC, Lee MS, Ho HN, Tsai RT. Genotypes of human polyomaviruses in urine samples of pregnant women in Taiwan. J Med Virol. 1996:48:95-101.

88. Boldorini R, Veggiani C, Amoruso E, Allegrini S, Miglio U, Paganotti A, Ribaldone R, Monga G. Latent human polyomavirus infection in pregnancy: investigation of possible transplacental transmission. Pathology. 2008;40:72-7.

89. Kling CL, Wright AT, Katz SE, McClure GB, Gardner JS, Williams JT, Meinerz NM, Garcea RL, Vanchiere JA. Dynamics of urinary polyomavirus shedding in healthy adult women. J Med Virol. 2012;84:1459-63.

90. Csoma E, Sápy T, Mészáros B, Gergely L. Novel human polyomaviruses in pregnancy: higher prevalence of BKPyV, but no WUPyV, KIPyV and HPyV9. J Clin Virol. 2012;55:262-5.

\section{Publisher's Note}

Springer Nature remains neutral with regard to jurisdictional claims in published maps and institutional affiliations.
Ready to submit your research? Choose BMC and benefit from:

- fast, convenient online submission

- thorough peer review by experienced researchers in your field

- rapid publication on acceptance

- support for research data, including large and complex data types

- gold Open Access which fosters wider collaboration and increased citations

- maximum visibility for your research: over $100 \mathrm{M}$ website views per year

At BMC, research is always in progress.

Learn more biomedcentral.com/submissions 